\title{
Homeobox Protein Hox-A7
}

National Cancer Institute

\section{Source}

National Cancer Institute. Homeobox Protein Hox-A7. NCI Thesaurus. Code C105434.

Homeobox protein Hox-A7 (230 aa, $25 \mathrm{kDa}$ ) is encoded by the human HOXA7 gene.

This protein is involved in anterior-posterior patterning during embryonic development. 